\title{
ANALISIS STILISTIKA PUISI GRESLA MAMOSO KARYA AMING AMINOEDHIN
}

\author{
Sita Khoiriah, Ali Nuke Affandy, Insani Wahyu Mubarok \\ Universitas Muhammadiyah Surabaya \\ insanialam@gmail.com
}

\begin{abstract}
ABSTRAK
Kumpulan puisi Gresla Mamoso karya Aming Aminoedhin banyak menggunakan pemanfaatan kosa kata bahasa jawa. Karena kebanyakan puisi Aming berkisah tentang jaman manusia purba dan jaman penjajahan Belanda. Masalah dalam penelitian ini adalah (1) Bagaimana penggunaan gaya bahasa dalam puisi Gresla Mamoso (2) Bagaimana penggunaan diksi dalam puisi Gresla Mamoso. Metode pengumpulan data yang digunakan adalah metode dokumentasi dan metode analisis isi. Sedangkan metode analisis data yang digunakan adalah (1) Reduksi Data, yaitu data yang diperoleh dicatat dalam uraian yang terperinci. (2) Penyajian Data, pada tahap ini data yang sudah ditetapkan kemudian disusun secara teratur dan terperinci. (3) Penarik Kesimpulan, pada tahap ini data yang diperoleh dibuat kesimpulan sehingga yang diperoleh benar-benar valid. Berdasarkan hasil penelitian terdapat beberapa gaya bahasa yangterkandung didalamnya, antara lain: gaya bahasa asonansi, repetisi, hiperbola, paralelisme, dan personifikasi.
\end{abstract}

Kata Kunci: Diksi, Gaya Bahasa, Stilistika

\begin{abstract}
Gresla Mamoso collections of poetry written by Aming Aminoedhin uses a lot Javanese vocabularies. Since most of Aming's poetries revolves the ancient human era and the Dutch colonial era. Problems in this research are (1) How is language style used in Gresla Mamoso (2) How does the use of diction in the poem Gresla Mamoso. Data collection methods used are documentation and content analysis. While the data analysis methods used are (1) reduction of data, ie data obtained are recorded in the detailed description. (2) the presentation of the data, at this stage the data that have been set is then compiled in order and in detail. (3) conclusion, at this stage the data obtained are inferred so that become valid. Based on the results of research, there are some stylistic language styles: stylistic assonance, repetition, hyperbole, parallelism, and personification.
\end{abstract}

Keywords: diction, language style, stylistic

\section{PENDAHULUAN}

Pada umumnya, manusia menyukai keindahan karena sesuatu yang indah itu akan terasa nyaman dan menentramkan hati. Keindahan dapat menimbulkan perasaan senang, bahagia, puas, tenang, nyaman, dan menimbulkan kenikmatan 
tersendiri. Manusia tak dapat lepas dari keindahan, karena manusia selalu membutuhkan ketenangan dan kesenangan. Hal ini adalah alasan mengapa manusia menyukai keindahan. Keindahan (estetika) berasal dari kata indah, artinya bagus, permai, cantik, elok, molek dan sebagainya. Benda yang mempunyai sifat indah ialah segala hasil seni, (meskipun tidak semua hasil seni indah, pemandangan alam (pantai, pegunungan, danau, bunga-bunga di lereng gunung), manusia (wajah, mata, bibir, hidung, rambut, kaki, tubuh), rumah (halaman, taman, perabot rumah tangga dan sebagainya), suara, warna dan sebagainya. Keindahan adalah identik dengan kebenaran.

Berdasarkan ciptaanya, karya sastra sebagaimana juga merupakan sebuah keindahan. Keindahan itu muncul dari gaya bahasa yang digunakan dalam karya sastra tersebut. Dalam hal ini gaya bahasa yang digunakan dalam karya sastra berhubungan erat dengan stilistika yang terkadung di dalamnya. Berdasarkan uraian tersebut peneliti tertarik mengangkat hal paling dasar untuk membedah makna sebuah karya sastra yaitu dengan menganalisis unsur- unsur pembangun karya sastra yang dalam hal ini dikhususkan pada analisis stilistika Gresla Mamoso karya Aming Aminoedhin, dkk.

Penulis memilih Aming Aminoedhin karena pemilik nama asli Muhammad Amir Tohar lahir sebagai penulis yang berasal dari Ngawi, Jawa Timur. Aming yang merupakan alumni mahasiswa Fakultas Sastra Universitas Sebelah Maret jurusan bahasa dan sastra Indonesia itu aktif dalam kegiatan teater dan pernah menyabet predikat actor terbaik se- Jawa Timur tahun 1983. Bagi Aming Aminoedhin puisi adalah makanan pokok. Alasan lain penulis memilih Aming dikarenakan dalam buku Gresla Mamoso ini sosok aming mengangkat tema yang menarik. Tema yang dipakai didalamnya banyak mengusung tempat-tempat yang berada di sekitaran wilayah Ngawi kota kelahirannya. Setiap sajak-sajaknya merupakan harmonisasi kata yang indah membentuk unsur metafora yang indah pula. Dengan kata-kata yang tidak berbelit-belit, unsur kata yang penuh renungan untuk pembaca. Secara garis besar memang karya Aming Aminoedhin cocok untuk memupuk nilai moral, nilai sosial, nilai cinta dan bangga pada daerah. 


\section{METODE PENELITIAN}

Metode deskriptif kualitatif ini bertujuan untuk membuat pencandraan secara sistematis, factual, dan akurat mengenai fakta-fakta dan sifat-sifat populasi atau daerah tertentu. Dengan demikian penggunaan metode kualitatif ini dimaksudkan untuk memecahkan masalah yang ada.

\section{PEMBAHASAN}

Sesuai dengan masalah yang diteliti, maka sebelum peneliti menyampaikan hasil penelitian secara lengkap berikut ini adalah gambaran puisi dalam Gresla Mamoso karya Aming Aminoedhin, dkk. Berikut ini adalah analisis rincinya.

\section{Analisis Gaya Bahasa}

a. Gaya Bahasa Asonansi

Asonansi yaitu gaya bahasa yang berwujud perulangan bunyi vokal yang sama. Beberapa data di bawah ini menggunakan gaya bahasa Asonansi.

(1) Terasa tanpa ada takut menghadang Hanya ada kata satu senang (PKB/GBA/H46)

(2) Jika tak jadi gila ketika mereka (TBP/GBA/H49)

(3) Menyusuri kembali sungai sepi (TBS/GBA/H50)

(4) Lalu keajaiban itu tiba tanpa dinyana Menjadi ada segala-galanya

(5) Barangkali harta, tahta dan wanita (KSSW/GBA/H28)

Pada data (1) (2) (4) (5) terdapat perulangan bunyi vokal /a/ pada akhir kata" terasa, tanpa, ada, hanya, ada, kata, tiba, tanpa, dinyana, harta, tahta, wanita". Perulangan vokal /a/ pada akhiran kata seperti itulah yang disebut Asonansi.

b. Gaya Bahasa Repetisi

Repetisi ialah perulangan kata, frase, dan klausa yang sama dalam suatu kalimat atau wacana. Di bawah ini adalah data yang termasuk dalam gaya bahasa Repetisi. 
(1) Meski tak harus lagi lewat sungai

Meski tak lagi berumah di gua

(PKB/GBR/H47)

(2) Membungkam manusia jawa

Membungkam tentara desersi

(3) Seperti mengigau

Seperti setan

(TBS/GBR/H50)

(SML/GBR/H43)

(4) Hari-hari berlalu hanya semu

Hari-hari kian kaku melaju

(HHBKK/GBR/27)

Pada data (1) terdapat perulangan frase "meski tak". Pada data (2) terdapat perulangan kata "membungkam". Pada data (3) terdapt perulangan kata "seperti". Pada data (4) terdapat perulangan kata "hari-hari”. Perulangan kata atau frase yang terdapat pada data diatasantara baris pertama dan kedua itulah yang disebut dengan gaya bahasa Repetisi.

c. Gaya Bahasa Hiperbola

Hiperbola adalah cara pengungkapan dengan me-lebih-lebihkan kenyataan sehingga kenyataan itu menjadi tidak masuk akal. beberapa data di bawah ini menggunakan gaya bahasa Hiperbola.

(1) Temuan itu gemparkan dunia

(2) Segalak cuaca kemarau kota Ngawi

Panas, sepanas neraka dunia

(TMK/GBH/H48)

(TBP/GBH/H49)

Pada data (1) "temuan itu gemparkan dunia" dengan maksud bahwa ada sebuah penemuan baru manusia purba, sehingga seluruh dunia gempar. Pada data (2) "segalak cuaca kemarau" maksudnya saking kemaraunya kota Ngawi, gersang, kering diibaratkan watak manusia yang galak. Sedangkan "panas, sepanas neraka dunia" maksudnya pada pengertian umum didalam neraka terdapat api yang sangat panas, panas yang terjadi saat musim kemarau sama dengan panas api neraka.

d. Gaya Bahasa Paralelisme

Paralelisme adalah pengungkapan dengan menggunakan frase klausa yang sejajar. Di bawah ini adalah data yang meng-gunakan gaya bahasa Paralelisme.

(1) Mencari bukur kerang

STILISTIKA Vol. 12 No. 2 Juli-Desember 2019
(PKB/GBP/H46) 
(2) Rasa ikhlas dan tabah hatimu bisa menghibur (CSM/GBP/H39)

Pada data (1) "bukur kerang" mempunyai makna sejajar keduanya merupakan benda laut yang dapat di konsumsi manusia. Pada data (2) "ikhlas dan tabah" juga mempunyai makna sejajar, keduanya merupakan perwatakan sifat baik manusia. Berdasarkan penjelasan tersebut karena memiliki makna yang sejajar atau hampir sama maka disebut gaya bahasa paralelisme.

e. Gaya Bahasa Personifikasi

Personifikasi adalah cara pengungkapan dengan menjadikan benda mati atau tidak benyawa sebagai manusia. Di bawah ini adalah data yang menggunakan gaya bahasa personifikasi.

(1) Lantaran kabut akan turun merumpun jadi embun

(2) Ketika mentari muncul perlahan (AKM/GBP/H26)

(3) Lihatlah cahaya mentari tetap berseri (AKM/GBP/H26)

(4) Tuhan tak pernah tidur kata ibuku (CSM/GBP/H39)

(5) Kau telah makan hati berulam jantungmu sendiri (HHBKK/GBP/H27)

Pada data (1) "kabut akan turun" maksudnya kabut itu di ibaratkan seperti manusia yang bisa berjalan turun dari atas ke bawah. Pada data (2) "mentari muncul perlahan" maksudnya mentari seolah-olah kadang sembunyi kadang muncul seperti kehidupan manusia. Pada data (3) "cahaya mentari tetap berseri" seolah-olah mentari bisa tersenyum seperti halnya manusia. Pada data (4) "Tuhan tak pernah tidur" dapat diartikan bahwa seolah-olah Tuhan itu berkehidupan seperti manusia tidur, makan, bekerja, dll. Pada data (5) "kau telah makan hati" maksudnya kadang perkataan manusia ada yang membuat orang lain tersinggung, maka di-ibaratkan makan hati. Berdasarkan penjelasan tersebut dapat disimpulkan bahwa data (1) sampai (5) termasuk dalam gaya bahasa Personifikasi. 


\section{Analisis Diksi}

a. Denotasi

Denotasi adalah konsep dasar yang didukung oleh satu kata (makna itu menunjuk pada konsep, referen atau ide). Denotasi mengacu pada makna yang sebenarnya. Di bawah ini adalah data yang menggunakan makna denotasi.

(1) Telah seratus sebelas tahun lalu

(TMK/D/H48)

(2) Dua puluh enam tahun lalu

(3) Dunia lain yang berjuta-juta mil jauhnya (PMP/D/H42)

Dari data (1) (2) (3) dapat disimpulkan bahwa ketiga data tersebut benarbenar terjadi dimasa silam dalam kehidupan manusia. Maka ketiga data tersebut termasuk dalam denotasi.

b. Kata Ilmiah

Kata Ilmiah adalah kata yang biasanya dipakai oleh kaum terpelajar terutama dalam tulisan-tulisan ilmiah. Di bawah ini adalah data yang termasuk dalam kata ilmiah.

(1) Fosil manusia kera itu sudah ditemu

(2) Lantaran desersi Konon, sipir penjaranya galak

(3) Geram kau pelihara Belati menikam jantungmu Hanya gincu indah memerah begitu semu (KSSW/KI/H28)

(4) Berjalan seakan pentas drama tanpa konflik (HHBKK/KI/H27)

(5) Membawa meriam

(TMK/KI/H48)

(TBP/KI/H49) (TBS/KI/H50)

Dari data diatas "fosil (tulang)", "desersi (berontak)", "sipir (pengawas)", "'geram (kesal)", "belati (pisau)", "gincu (lipstick)", "konflik (masalah)", meriam (tembak/bedil)". Kata kata ilmiah tersebut bagi masyarakat umum masih sulit dipahami, hanya kaum terpelajar yang biasanya memakai.

c. Kata Umum

Kata umum adalah kata yang mempunyai cakupan ruang lingkup yang sangat luas. Kata umum menunjuk kepada banyak hal, kepada himpunan dan kepada keseluruhan. Di bawah ini adalah data yang menggunakan kata umum. 
(1) Menyusuri kembali sungai sepi

(TBS/KU/H50)

(2) Musibah itu hanya kepadamu muaranya (CSM/KU/H39)

Data (1) terdapat kata "sungai". Kata tersebut bisa menunjuk kepada banyak hal, sungai tidak dijelaskan secara terperinci atau secara jelas macam atau jenisnya. Data (2) terdapat kata "musibah". Musibah juga bisa mengacu kepada banyak hal. Misalkan saja jenis musibah ada tanah longsor, gempa bumu, gunung meletus, dll. Maka dari itu kata sungai dan musibah termasuk dalam kata umum.

d. Kata Khusus

Kata Khusus adalah kata-kata yang mengacu kepada pengarahan-pengarahan yang khusus. Berikut ini adalah data yang termasuk dalam kata khusus.

(1) Atau sesudah Adam ada Wilayah Mojopahit

Yang kini bernama Mojokerto

(TMK/KK/H48)

(2) Dari Sangiran hingga Trinil (PMP/KK/H42)

Data (1) terdapat kata "adam (salah satu nama nabi)", "Mojopahit (salah satu kerajaan yang ada di Jawa)", "Mojokerto (salah satu kota yang ada di Jawa Timur) sedangkan data (2) "Sangiran dan Trinil (nama museum manusia purba di Jawa). Dari data (1) dan data (2) dapat disimpulkan bahwa keduanya termasuk dalam kata khusus karena hanya mengacu kepada hal-hal yang bersifat khusus.

\section{PENUTUP}

Berdasarkan analisis yang dilakukan, gaya bahasa yang terdapat dalam puisi Gresla Mamoso karya Aming Aminoedhin adalah gaya bahasa Asonansi. Dalam Gresla Mamoso Asonansi didominasi oleh perulangan bunyi vokal /a/ dan vokal /i/. Selain gaya bahasa Asonansi terdapat juga gaya bahasa Repetisi, Hiperbola, Paralelisme, dan Personifikasi. Sedangkan hasil dari penelitian stilistika diksi berdasar atas jenis- jenis diksi menurut Keraf terdapat aspek-aspek penggunaan diksi yaitu banyak pemanfaatan kosakata Bahasa Jawa didalamnya. Selain itu juga juga terdapat kata ilmiah sejumlah tujuh untuk memperkuat isi puisi yang kebanyakan menceritakan tentang peristiwa masa lalu jaman penjajahan Belanda. 


\section{DAFTAR RUJUKAN}

Arikunto, Suharsimi. 2006. Prosedur Penelitian. Jakarta: PT Rineka Cipta.

Endraswara, Suwardi. 2011. Metodologi Penelitian Sastra - Epistemologi, Model, Teori, dan Aplikasi. Yogyakarta: CAPS.

Keraf, Gorys. 2000. Diksi dan Gaya Bahasa. Jakarta: PT Gramedia Pustaka Utama.

Kridalaksana, Harimurti. 2008. Kamus Linguistik. Jakarta: PT Gramedia Pustaka Utama.

Ratna, Nyoman Kutha. 2013. Stilistika. Yogyakarta: Pustaka Pelajar.

Tjahjono, Tengsoe, dkk. 2013. Gresla Mamoso. Lamongan: Forum Sastra Bersama Surabaya.

Wellek, Rene dan Austin Warren. 1998. Teori Kesusastraan. Jakarta: PT Gramedia. 